\title{
PENGARUH KUALITAS TENAGA PENDIDIK TERHADAP PENDIDIKAN DI INDONESIA
}

\author{
Nursahid \\ Email: 2010128210012@mhs.ulm.ac.id \\ Program Studi Pendidikan IPS Fakultas Keguruan dan Ilmu Pendidikan \\ Universitas Lambung Mangkurat \\ Banjarmasin
}

\begin{abstract}
Abstrak
Tenaga pendidik ialah unsur yang paling penting pada bidang pendidikan dalam tujuan mengembangkan serta meningkatkan kualitasnya pada pendidikan. meningkatkan kualitas tenaga pendidik bisa diartikan aktivitas yang sedang dilakukan si tenaga pendidik dalam mengamalkan ilmu serta pengetahuan dan keterampilan dalam tujuan meningkatkan kualitas pada proses berlangsungnya kegiatan belajar mengajar serta profesionalnya tenaga pendidikan atau dalam tujuan memperoleh sesuatu yang memiliki manfaat bagi kebudayan serta pendidikan. meningkatkan kualitas tenaga pendidik terdapat 4 strategi yaitu dari aspek profesional, pedagogik, sosial dan kepribadian. kualitas seorang guru dapat menentukan masa depannya siswa/i. Karena guru adalah SDM yang ikut serta memiliki peran yang sangat penting untuk mewujudkan siswa/i yang cerdas sesuai dengan tujuan dari pendidikan nasional.
\end{abstract}

Kata Kunci: Tenaga pendidik, Masalah pendidikan dan Kualitas pendidik.

\section{PENDAHULUAN}

Negara Indonesia merupakan bagian yang masih berkembang. Agar menjadi bagian yang maju maka Negara Indonesia harus terus mengembangkan semua sektor, Seperti sektor 
ekonomi. Kemudian tidak hanya sektor ekonomi saja yang harus di kelola. Bisa juga sektor pada bidang pendidikan yang harus dikembangkan. Karena pendidikan bisa dianggap sebagai penentu dalam semua bidang. Bisa dikatakan disini adalah bahwa orang yang tidak menempuh pendidikan maka bagaikan masakan yang tanpa diberi garam maupun gula. Kemudian dalam bidang pendidikan yang sangat mencolok atau yang memiliki peran sangat besar adalah seorang pendidik atau yang bisa dikatakan profesi seorang guru. Di Indonesia memang sering terjadi maraknya masalah putus sekolah yang disebabkan dari mereka yang sulit mencari nafkah untuk biaya sekolah sang anak namun kemudian jalan terakhir berhenti dan ikut melakukan pekerjaan yang sedang maraknya saat ini seperti badut jalanan (Putra et al., 2021: 123). Kemudian tidak hanya itu saja, nilai pembelajaran yang rendah serta kurangnya kualitas dari tenaga pendidik sehingga putus sekolahlah jalan yang tak bisa dihindarkan oleh peserta didik sehingga menyebabkan masalah yang serius (Rusmaniah et al., 2021: 152).

Pada bidang pendidikan yang berlangsungnya dalam kegiatan pembelajaran maka seorang tenaga pendidik pasti akan menghadapi dengan berbagai macam persoalan yang berupa murid, materi ajar serta metode yang akan digunakan pada saat pembelajaran (Arisanty et al, 2018: 1). Kemudian menurut (Arisanty et al., 2018: 1) dalam karyanya yaitu "profesional sebagai guru harus bisa membuat keprofesionalannya seperti penilaian yang didasari pada data yang ada serta akuratnya dalam mencetuskan suatu teori. Kemudian wajib meningkatkan kualitas pada saat berlangsungnya pembelajaran terjadi secara penting dalam guna menunjang prestasi kemudian kepuasan yang ada pada tingkat yang tinggi pada peserta didik". Masalah yang sering terjadi pada bidang pendidikan negara Indonesia adalah kekurangan tenaga pendidik atau guru untuk meningkatkan kemampuan yang dimiliki dengan maksimal. Kemudian untuk melaksanakan kegiatan pembelajaran sulit dimengerti serta membuat peserta didiknya tidak menarik dalam mengikuti kegiatan pembelajaran mengajar yang sedang berlangsung. Sedangkan menurut (Putro, 2013: 39) menyatakan bahwa "pada saat situasi dalam pengembangan pada saat sekarang sudah jadi pandangan K13. Kemudian pintu pada pembelajaran sudah dikembangkan dengan K13(kurikulum 2013) yang dimana gunanya murid menjadi murid pada zamannya yang dimana sesuai dengan ciri 
karakternya pada masa kini seperti aktif, kreatif serta inovatif yang sesuai dengan hakikat ilmu yang ilmiah". Dengan demikian tujuan penulisan artikel ini adalah membahas "bagaimana pengaruh kualitas tenaga pendidik pada pendidikan dalam keprofesionalan guru?"

\section{HASIL DAN PEMBAHASAN}

\section{PENNGERTIAN TENAGA PENDIDIK}

Pada pasal 39 UU No. 20 thn 2003 ayat $1 \& 2$ yang berisikan Sisdiknas seperti tenaga pendidik ialah seorang profesional yang memiliki tugas melakukan rencana serta melakukan suatu menilai serta proses dalam pembelajaran, kemudian melaksanakan bimbingan serta pelatihan, penelitian dan mengabdi pada masyarakat karena tugas penting bagi tenaga pendidik yang ada di perguruan tinggi (Ramadhani, 2019: 2). Sedangkan dalam Pandangan Ki Hajar Dewantara menyatakan bahwa "seorang pendidik wajib bisa dalam menjadi sosok yang teladan bagi peserta didiknya serta orang lain yang ada pada kehidupan dalam bermasyarakat berbangsa serta bernegara (Fauzi, 2017: 4). Sehingga dapat dikatakan bahwa tenaga pendidik ialah unsur yang paling penting pada bidang pendidikan dalam tujuan mengembangkan serta meningkatkan kualitasnya pada pendidikan. karena tenaga pendidik tersebut memiliki pengaruhnya yang sangat besar terhadap pendidikan dalam menghasilkan

generasi emas yang dimana berguna untuk memajukan bangsa negara Indonesia dalam 100thn setelah kemerdekaannya.

Waktu yang terus berlalu cepat dengan perkembangan yang terjadi pada dunia pendidikan. Sehingga pihak yang bersangkutan pada dunia pendidikan diwajibkan untuk lebih mengembangkan kemampuan yang sudah dimiliki pendidik agar tidak ketinggalan dengan zaman yang sudah berkembang dengan maju yang dimana semakin berkembang suatu zaman maka semakin canggihnya yang terjadi pada teknologi. Sehingga sebagai tenaga pendidik harus memberikan pelajaran yang sesuai dengan berkembangnya zaman. Agar membuat peserta didiknya berubah jadi peserta didik yang unggul serta kompeten pada setiap saat serta di semua bidang yang ia geluti. 


\section{TUJUAN MENINGKATKAN KUALITAS TENAGA PENDIDIK \& PENGARUHNYA TERHADAP PENDIDIKAN}

Dalam meningkatkan kualitas tenaga pendidik bisa diartikan aktivitas yang sedang dilakukan si tenaga pendidik dalam mengamalkan ilmu serta pengetahuan dan keterampilan dalam tujuan meningkatkan kualitas pada proses berlangsungnya kegiatan belajar mengajar serta profesionalnya tenaga pendidikan atau dalam tujuan memperoleh sesuatu yang memiliki manfaat bagi kebudayan serta pendidikan. Dalam tujuannya dalam meningkatkan kualitas tenaga pendidik berupa membuat pembelajaran lebih efisien serta efektif. Guru yang tidak meningkatkan kualitasnya maka bagaikan barang yang dipakai secara berkepanjangan dan kemudian tidak diganti barang tersebut untuk mendapat kualitas yang bagus yang sesuai dengan berkembangannya zaman maka akan rusaklah barang tersebut. Sehingga guru wajib melakukan hal tersebut sesuai berkembangnya zaman. Agar memperoleh peserta didik yang dapat bersaing di kancah internasional demi membuat negara Indonesia menjadi negara yang daoat berdaya saing yang tinggi.

Dalam meningkatkan kualitas tenaga pendidik terdapat 4 strategi yaitu dari aspek profesional, pedagogik, sosial dan kepribadian. Pada aspek profesional yang harus dipunyai guru adalah pada saat menguasai materi untuk pembelajaran yang luas serta mendalam harus dikuasai oleh pendidik yang sesuai kurikulum mata pelajaran pada jenjang pendidikan. kemudian harus bisa memilih dan memilah serta juga mengelompokan materi ajar untuk pembelajaran yang nantinya disampaikan pada peserta didik yang sesuai dan mengedepankan potensi sang guru dalam menampilkan bahan ajar. Sehingga guru wajib memahami pada disiplin ilmu yang sudah dikuasai serta dapat mempertanggungjawabkannya. Pada aspek potensi pedagogik ialah keahlian dalam memahami serta mengelola dalam pembelajaran yang dapat mendidik peserta didik. Pada aspek sosial dalam kemampuan guru adalah potensi guru yang berupa dari bagian masyarakat untuk berinteraksi dengan cara yang efektif pada peserta didik, sesama guru, orang tua dari peserta didik serta pada masyarakat sekitarnya. Dan dalam aspek kepribadian ialah potensi individu yang memiliki cerminan pribadi yang bagus, seimbang, memiliki akhlak baik, wibawa, serta dapat jadi contoh bagi peserta didik. 
Dengan kata lain merupakan panutan bagi peserta didik karena pendidik dianggap selalu mengikuti pedoman pada beberapa norma yang sudah ada pada lingkungan masyarakat (Susanto, 2020: 62-80).

Pengaruhnya pada kualitas tenaga pendidik adalah sangat penting. Pengaruhnya dapat berupa perubahan intelektual serta moral yang sangat khas berasal dari muatan pemikiran yang dapat memungkinkan tercapainya suatu integrasi dalam hubungan interaksi sosial. integrasi yang dimaksud ciri khas perkembangan yang terjadi pada 13 sampai 21 tahun (Rusmaniah et al., 2021: 154). Kemudian dapat memberi binaan yang berupa pengetahuan terhadap peserta didik yang berisi pengalaman individu didalam kehidupan yang bermasyarakat yang terjadi pada saat lampau atau sekarang serta dimasa yang akan terjadi kedepannya (Mutiani et al., 2019: 16). Sehingga dapat dikatakan bahwa kualitas seorang guru dapat menentukan masa depannya siswa/i. Karena guru adalah SDM yang ikut serta memiliki peran yang sangat penting untuk mewujudkan siswa/i yang cerdas sesuai dengan tujuan dari pendidikan nasional. Sehingga tenaga pendidik diwajibkan selalu meningkatkan kualitasnya. Kualitas tenaga pendidik dapat mempengaruhi jalan pendidikan terhadapa peserta didik. Apabila tenaga pendidik tidak melakukan peningkatan terhadap kualitas dalam pembelajaran maka peserta didik pun akan bosan karena metode dalam menyampaikan materi ajarnya seperti itu terus sehingga menimbulkan peserta didik malas untuk sekolah. Jadi, tenaga pendidik yang selalu melakukan peningkatan terhadap kualitasnya maka ia akan mendapatkan pencapaian yang sesuai dengan usahannya seperti tujuan mengajar, gaji meningkat, kenaikan jabatan dan lainnya.

\section{SIMPULAN}

Tenaga pendidik ialah unsur yang paling penting pada bidang pendidikan dalam tujuan mengembangkan serta meningkatkan kualitasnya pada pendidikan. karena tenaga pendidik tersebut memiliki pengaruhnya yang sangat besar terhadap pendidikan dalam menghasilkan generasi emas yang dimana berguna untuk memajukan bangsa negara Indonesia dalam 100thn setelah kemerdekaannya. Sebagai tenaga pendidik harus 
memberikan pelajaran yang sesuai dengan berkembangnya zaman. Agar membuat peserta didiknya berubah jadi peserta didik yang unggul serta kompeten pada setiap saat serta di semua bidang yang ia geluti. Meningkatkan kualitas tenaga pendidik bisa diartikan aktivitas yang sedang dilakukan si tenaga pendidik dalam mengamalkan ilmu serta pengetahuan dan keterampilan dalam tujuan meningkatkan kualitas pada proses berlangsungnya kegiatan belajar mengajar serta profesionalnya tenaga pendidikan atau dalam tujuan memperoleh sesuatu yang memiliki manfaat bagi kebudayan serta pendidikan. tujuannya dalam meningkatkan kualitas tenaga pendidik berupa membuat pembelajaran lebih efisien serta efektif. Guru yang tidak meningkatkan kualitasnya maka bagaikan barang yang dipakai secara berkepanjangan dan kemudian tidak diganti barang tersebut untuk mendapat kualitas yang bagus yang sesuai dengan berkembangannya zaman maka akan rusaklah barang tersebut. meningkatkan kualitas tenaga pendidik terdapat 4 strategi yaitu dari aspek profesional, pedagogik, sosial dan kepribadian.

Pengaruhnya pada kualitas tenaga pendidik adalah sangat penting. Pengaruhnya dapat berupa perubahan intelektual serta moral yang sangat khas berasal dari muatan pemikiran yang dapat memungkinkan tercapainya suatu integrasi dalam hubungan interaksi sosial. Kualitas tenaga pendidik dapat mempengaruhi jalan pendidikan terhadapa peserta didik. Apabila tenaga pendidik tidak melakukan peningkatan terhadap kualitas dalam pembelajaran maka peserta didik pun akan bosan karena metode dalam menyampaikan materi ajarnya seperti itu terus sehingga menimbulkan peserta didik malas untuk sekolah.

\section{REFERENSI}

Arisanty, D., Putro, H. P. N., Wahyu, W., Anis, M., Arifin, Z., \& Syarifuddin, S. (2018). Pengembangan Keprofesionalan Guru Melalui Penelitian Tindakan Kelas (PTK) di SMP Negeri 1 Alalak Kec. Alalak Kab. Barito Kuala.

Fauzi, A. (2017). Manajemen Pengembangan Tenaga Pendidik di SD Islam Al Azhar 39 Purwokerto. 
Mutiani, M., Subiyakto, B., Jumriani, J., Aslamiah, A., \& Afrina, A. (2019). Laporan Penelitian: Relevansi Modal Sosial Dalam Pembelajaran IPS (Studi Kasus Dalam Sistem Zonasi Di Smp Negeri Kota Banjarmasin).

Putra, M. A. H., Rahman, A. M., Jumriani, J., Abbas, E. W., \& Subiyakto, B. (2021). The Street Clowns in Banjarmasin City as a Life Survival Strategy. The Innovation of Social Studies Journal, 2(2), 121-126.

Putro, H. P. N. (2013). Pengembangan Pembelajaran IPS dalam Kurikulum 2013. Mewacanakan Pendidikan IPS, 39.

Ramadhani, S. (2019). PENGERTIAN DAN PROSES ADMINISTRASI PENDIDIK DAN TENAGA KEPENDIDIKAN.

Rusmaniah, R., Mardiani, F., Handy, M. R. N., Putra, M. A. H., \& Jumriani, J. (2021). Social Services Based on Institutional for Youth Discontinued School. The Innovation of Social Studies Journal, 2(2), 151-158.

Susanto, H. (2020). Profesi Keguruan. Banjarmasin: FKIP Universitas Lambung Mangkurat. 